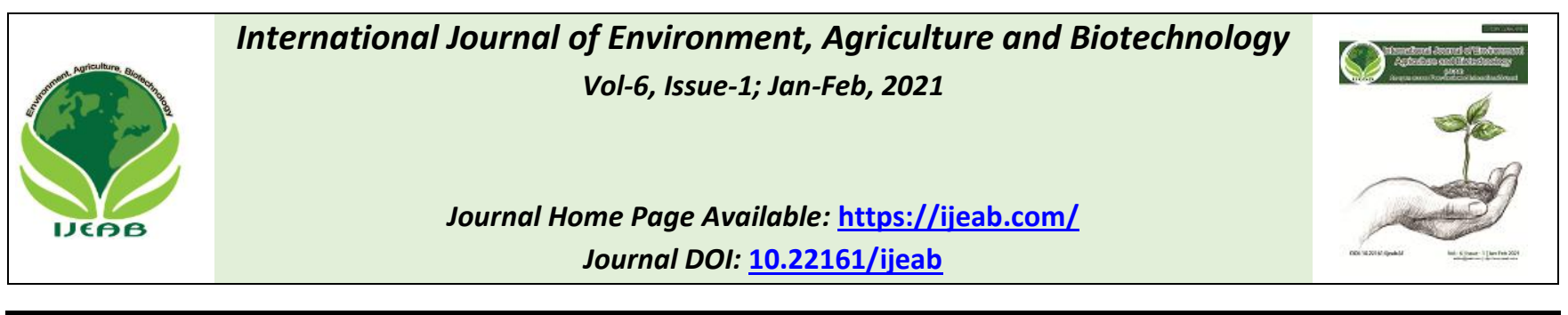

\title{
Inhibitory Activity of Distilled water and Ethanol Extracts of Moringa oleifera Leaves Against Enterobacter aerogenes
}

\author{
Andi Sayida Nurul Shafira ${ }^{1}$, Metusalach ${ }^{2}$, Nursinah $\mathrm{Amir}^{3}$ \\ ${ }^{1}$ Fisheries Science Study Program, Faculty of Marine and Fisheries Sciences, University of Hasanuddin, Makassar, Indonesia \\ ${ }^{2}$ Department of Fisheries, Faculty of Marine and Fisheries Sciences, University of Hasanuddin, Makassar, Indonesia \\ ${ }^{3}$ Department of Fisheries, Faculty of Marine and Fisheries Sciences, University of Hasanuddin, Makassar, Indonesia \\ *Corresponding Author
}

Received: 27 Oct 2020; Received in revised form: 05 Jan 2021; Accepted: 18 Jan 2021; Available online: 31 Jan 2021 (C)2021 The Author(s). Published by Infogain Publication. This is an open access article under the CC BY license (https://creativecommons.org/licenses/by/4.0/).

\begin{abstract}
Enterobacter aerogenes is one of the bacteria that has an important role in converting histidine to histamine in fish. When consumed, histamine in fish can cause poisoning and even death. The growth of bacteria that cause damage to fish can be inhibited in several ways, including the addition of compounds that have the potential to act as bacteriostatic or even bactericide. One of the plants that has the potential as a source of bactericide compounds is drumstic tree (Moringa oleifera Lamk.). This study aimed to determine the effectiveness of several concentrations of Moringa leaves extract using distilled water and ethanol in the inhibition of Enterobacter aerogenes bacteria as a histamine producer. The results showed that distilled water and ethanol extracts of Moringa leaves had an effective inhibition against Enterobacter aerogenes. The distilled water extract at a $40 \%$ concentration produced the largest inhibition zone $(14.73 \mathrm{~cm})$ while that of the ethanol extract at a $40 \%$ concentration was $10.57 \mathrm{~cm}$. The distilled water extract of Moringa leaves is suitable for use because it is cheap, practical, safe for consumption and does not leave any unsafe residue on food.

Keywords-Distilled watert extract, Enterobacter aerogenes, Ethanol extract, Inhibitory activities, Moringa oleifera Leaves.
\end{abstract}

\section{INTRODUCTION}

Enterobacter aerogenes is one of the bacteria present in the guts and gills of fish this bacterium has enzyme histidine decarboxylase capable of converting the amino acid histidine in fish into histamine in warm conditions [1]. Poisoning due to consuming foods containing high histamine are characterized by symptoms of a rash, nausea, vomiting and diarrhea and may even lead to death [2]. Histamine can also cause allergies in some people [3].

Histamine is a poisonous compound produced by several types of red meat fish, especially in the scromobidae family, due to the activity of bacteria and enzymes [4].

Among the histamine-forming bacteria such as using Raoultella terrigena, Enterobacter spp., Microbacterium testaceum, Brevibacterium mcbrellneri; Micrococcus diversus; Staphylococcus spp., the Enterobacter spp., have the greatest ability in forming histamine. Several types of the Enterobacter bacteria known to form histamine are Enterobacter aerogenes, Enterobacter agglomerans, Enterobacter amnigenus, Enterobacter cloacae, and Enterobacter intermedium [5].

The growth of bacteria that cause damage to fish can be inhibited in several ways, including the use of bactericide compounds. One of the plants that have the potential as a bactericide is Moringa [6]. Moringa oleifera or Moringa leaves contain bioactive compounds saponins, alkaloids, phytosterols, tannins, phenolics and flavonoids [7]. Moringa leaves have active compounds that act as antibacteria [8]. Moringa leaves extract can inhibit activities of several types of bacteria, such as Streptococcus sp., Pseudomonas fluoroscens, Proteus mirabilis and fungi Aspergillus flavus [9]. 
Moringa grows well in tropical and subtropical areas on all types of soil and its resists dry season with drought tolerance for up to 6 months [10]. Moringa leaves are easily be found throughout Indonesia. However, most Indonesians recognize Moringa leaves only as a vegetable dish that can be mixed with other types of vegetables [11]. So, it will be very useful if Moringa leaves can be used to inhibit the growth of bacteria, especially Enterobacter aerogenes as histamine-forming bacterium in fish.

This study, therefore aimed to determine the inhibitory activities of distilled water and ethanol extracts of Moringa oleifera leaves against bacteria Enterobacter aerogenes.

\section{MATERIALS AND METHODS}

\subsection{Collection of moringa leaves samples}

Moringa oleifera leaves ( $\pm 1 \mathrm{~kg}$ wet weight) were collected from Pinrang \& Selayar, South Sulawesi Province, Indonesia. The collected leaves were then cleaned and washed under running water. Upon drained, the leaves were air-dried under shade (Fig. 1a) to avoid direct sunlight exposure. The dried samples were then mashed into a powder form (Fig. 1b), sieved with a commercial sieve and stored in a closed glass container until used.

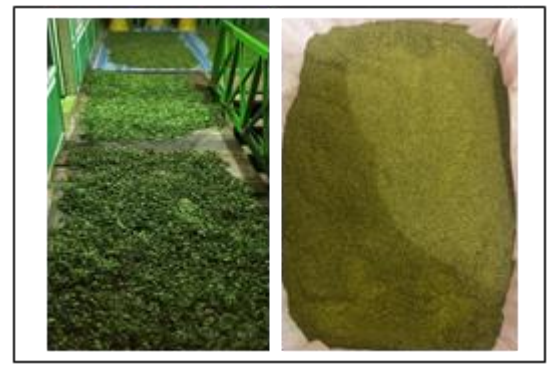

Fig 1. Air-drying process (a) Moringa leaves powder (b)

\subsection{Preparation of moringa leaves estract}

Extract of the Moringa leaves was prepared using two type of solvents, distilled water \& ethanol. Extraction was performed by macerating (Fig. 2) $100 \mathrm{~g}$ of Moringa leaves powder in $500 \mathrm{~mL}$ of either distilled water or ethanol (1:5, $\mathrm{w} / \mathrm{v})$ for $48 \mathrm{~h}$. The filtrate was then separated using Whatmann No. 1 filter paper. To recover solid extract, the water extract was lyophilized while the ethanol extract was dried using a vacuum rotary evaporator. The solid extract was stored in a capped vial until used.

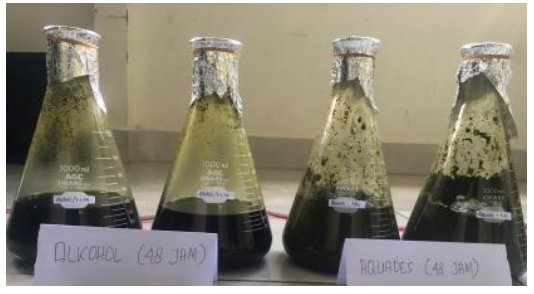

Fig.2: Maceration process for 48 hours

\subsection{Nutrient agar media preparation}

Nutrient agar (NA) media was aseptically prepared by dissolving $4 \mathrm{~g}$ nutrient agar powder in $200 \mathrm{~mL}$ of distilled water, then heating it to a boil with regular stirring. The prepared NA media was then sterilized in an autoclave at a temperature of $121^{\circ} \mathrm{C}$ for $15 \mathrm{~min}$ at a pressure of $1 \mathrm{~atm}$ [12].

While in warm conditions $\left(40-45^{\circ} \mathrm{C}\right)$ the sterile media was poured into $15 \mathrm{~mL}$ sterile petri dishes and allowed to stand until the media solidified.

\subsection{Bacterial rejuvenation}

Enterobacter aerogenes was obtained from the Indonesian Culture Collection LIPI, Indonesia, code InaCC B865. The bacteria were grown on NA media, inoculated using a loop needle etched on NA media then incubated at $30^{\circ} \mathrm{C}$ for 24 h.

\subsection{Preparation of bacterial suspension}

Preparation of the suspension test was carried out by taking a loopful of the isolate, suspend it in $2 \mathrm{~mL} 0.9 \%$ $\mathrm{NaCl}$ solution in a sterile test tube and then homogenizing it with a vortex. The turbidity of the suspension was then compared with that of the standard 0.5 McFarland (1.5 x $\left.10^{8} \mathrm{CFU} / \mathrm{mL}\right)$.

\subsection{Preparation of test solution extract}

The concentrations of the extract solution used in this study were $10,20,30$, and $40 \%$. These concentrations were made by thoroughly dissolving 25, 50, 75 and 100 $\mathrm{mg}$, respectively, of the dry extract in $250 \mu \mathrm{L}$ of DMSO. The negative control was $50 \mu \mathrm{L}$ DMSO and the positive control was $10 \mu \mathrm{g} / \mathrm{mL}$ of Amoxicillin.

\subsection{Inhibition test against $E$. aerogenes}

The inhibition test was performed following the KirbyBauer disk diffusion method. Warm NA media was poured into the sterile petri disk and let to cool. Further, the bacterial suspension of $100 \mu \mathrm{L}$ which was comparable to a standard suspension of $0.5 \mathrm{McF}$ arland $\left(1.5 \times 10^{8} \mathrm{CFU} / \mathrm{mL}\right)$ was added to the petri dishes. The bacterial suspension was spread evenly on the surface of the NA and let to stand for 5 min. Then, the paper discs pre-impregnated with test solution were placed on top of the NA containing bacteria 
and incubated for $24 \mathrm{~h}$ at $37^{\circ} \mathrm{C}$. Upon completion of incubation, the inhibitory activity was determined by measuring diameter of the inhibitory zone.

\subsection{Data analysis}

Data were analyzed by one-way ANOVA using the statistical package SPSS 26 for windows to determine the antibacterial effect of $M$. oleifera extract against $E$. aerogenes. The difference in antibacterial activity among the test treatments was assessed using Duncan's Multiple Range Test with an adjusted p-value at 0.05.

\section{RESULTS}

The antibacterial activity of the distilled water and ethanol extract of Moringa leaves was determined by measuring the diameter of the formed inhibition zone.. The antibacterial activity is present if there is a clear zone around the disc paper [13]. Figure 3 shows clear areas around the discs indicating the anti-bacterial activity of the Moringa leaves extracts.

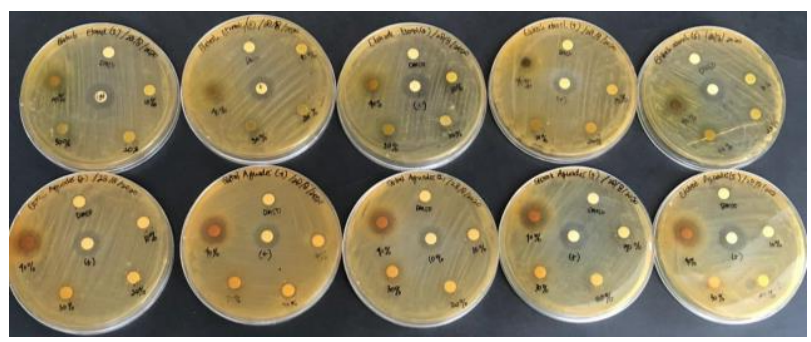

Fig 3: Inhibition zone of ethanol extract (upper row) \& distilled water extract (bottom row)

Both the ethanol and water extracts of Moringa leaves showed positive results. The Inhibition zone diameter of Moringa leaves extracts is presented in Table 1. The $40 \%$ distilled water extract showed the largest diameter of inhibition, which was $14.73 \mathrm{~mm}$, while the inhibition diameter of the positive control (Amoxicillin $10 \mu \mathrm{g} / \mathrm{ml}$ ) was $13.98 \mathrm{~mm}$ and the $40 \%$ ethanol extract was $10.57 \mathrm{~mm}$. This shows that the water extract of the Moringa leaves has an antibacterial ability comparable to the $10 \mu \mathrm{g} / \mathrm{ml}$ Amoxicillin antibiotic. The potential of an antimicrobial is estimated by comparing the growth inhibition zone to sensitive microorganisms from the inhibition of a concentration of a test solution to antibiotics [14].

Table 1. Diameter of Inhibitory Activities

\begin{tabular}{|c|c|c|}
\hline $\begin{array}{l}\text { Solvent } \\
\text { Extract }\end{array}$ & $\begin{array}{l}\text { Concentra } \\
\text { tion } \\
(\%)\end{array}$ & $\begin{array}{c}\text { Diameter of } \\
\text { Inhibition } \\
(\mathrm{mm})\end{array}$ \\
\hline Etahonlic & 10 & $7.01^{\mathrm{a}}$ \\
\hline
\end{tabular}

\begin{tabular}{llc} 
& 20 & $7.17^{\mathrm{a}}$ \\
& 30 & $8.17^{\mathrm{a}}$ \\
& 40 & $10.57^{\mathrm{b}}$ \\
Distilled watert & 10 & $7.90^{\mathrm{ab}}$ \\
& 20 & $8.13^{\mathrm{ab}}$ \\
& 30 & $9.56^{\mathrm{ab}}$ \\
& 40 & $14.73^{\mathrm{c}}$ \\
Positive Control & Amoxicilin & \\
& $10 \mu \mathrm{g} / \mathrm{ml}$ & $13.98^{\mathrm{c}}$ \\
Negative & & 0 \\
Control & DMSO & \\
\hline
\end{tabular}

The diameter of the zone of inhibition showed that the two extract at a $40 \%$ concentration had strong anti-bacterial activities in treating the E. aerogenes. The ability of the test material to inhibit the test bacteria is classified as very strong $(>20 \mathrm{~mm})$, strong $(11-19 \mathrm{~mm})$, moderate $(5-10 \mathrm{~mm})$ and weak $(<5 \mathrm{~mm})[15]$.

The results of ANOVA showed that the type of solvent and the concentration of the extract had significant effects on the activity of the E. aerogenes. The Duncan test showed that the distilled water extract of Moringa leaves at $40 \%$ showed a higher $(\mathrm{p}<0.05)$ inhibition activitiey against the E. Aerogenes compared to other concentrations of the water extract as well as to all concentrations of the ethanol extract tested. Previous study where three concentrations of [13] distilled water extract from $M$. oleifera had inhibitory diameters of $18,19,21 \mathrm{~mm}$ against $P$. vulgaris strain NCTC8196, while methanol and petroleum ether extracts did not show any effect on $P$. vulgaris bacteria [16]. P. vulgaris and E. aerogenes are of the same family.

The difference in the diameter of the inhibition zone between the distilled water and the ethanol extracts of Moringa leaves is caused by differences in the degree of polarity of each solvent. The polarity of distilled water is 9.0, while that of $96 \%$ ethanol is about 5.2. The principle of extraction is that polar substances only in polar solvents, and non-polar substances only dissolve in non-polar solvents [16]. The polarity of the solvent used determines the amount of the active substances because, in the extraction process, the principle of "like dissolves like" applies where the substance will only dissolve properly and get static if the solvent used has the same polarity level [17].

The phytochemical test results showed that the distilled water extract of Moringa leaves contained flavonoids and alkaloids. The ethanol, methanol, and ethyl acetate extracts of Moringa leaves contained alkaloid but they did not 
contain flavonoids, whereas the n-hexane extract did not contain both alkaloids and flavonoids [18]. However, other study showed that the extract of Moringa leaves macerated in ethanol contained flavonoids and polyphenols [19]. The distilled water extract also contained steroids, triterpenoids, flavonoids, saponins, phenols, and tannins [12]. Nonetheless, both the distilled water and the ethanol extracts of Moringa leaves have the antibacterial ability. Still, the level of inhibition is different based on the solvent's degree of polarity.

The flavonoids, polyphenols, saponins, and tannins are active compounds in Moringa leaves with antibacterial properties [20]. According to [21], the flavonoid compounds in Moringa leaves extract have the same polarity as distilled water. Flavonoids are polyphenol group compounds widely distributed in plants in the form of glycosides that bind to sugar. Flavonoids are divided into several types, and each type has a different polarity depending on the number and position of the hydroxyl groups [21]. Polar solvents commonly used for flavonoid extraction are methanol, acetone, ethanol, water, and isopropanol.

Water as a solvent is polar, cheap, easy to obtain, stable, non-toxic, non-volatile, and flammable [22]. Water is also a recommended solvent for the food industry because it's leaves no residue in the extraction results so that the resulting product is safe for consumption [23].

According to [24], water is often referred to as the universal solvent because it dissolves many chemicals. Water is in a dynamic balance between the liquid and solid phases under standard pressure and temperature. In ionic form, water can be described as a hydrogen ion $(\mathrm{H}+)$ in association (bonding) with a hydroxide ion (OH-).

Ethanol is a volatile liquid commonly used as a solvent for most organic compounds. Ethanol, which is a semipolar solvent, can dissolve both polar and non-polar compounds. Semi-polar solvents can induce polarity of non-polar solvent molecules. It acts as an intermediate solvent to mix non-polar and non-polar solvents. Ethanol has a high selectivity for reactions [25]. Therefore, selection of solvent must consider several factors, including selectivity, ability to extract, toxicity, ease of evaporation, and solvent price [25].

\section{CONCLUSION}

The present study demonstrated that both the distilled water and the ethanol extracts of the Moringa leaves exhibited an antibacterial activity against E. aerogenes. At high concentration $(40 \%)$, the antibacterial activity of the distilled water extract was more powerful than that of the ethanol extract. Nevertheless, both extracts were similar in their anti E. aerogenes activity at the concentrations of up to $30 \%$. Since distilled water is considered to be safer than ethanol, it is recommended to use water for extraction of anti E. aerogenes from the Moringa leaves, especially if the extract is intended to be used to preserve food products. However, further study using different types of pathogenic and/or spoilage bacteria is warranted.

\section{REFERENCES}

[1] Y. S. Fatuni, S. Ruddy, dan J. M. Agus, "Identifikasi Kadar Histamin dan Bakteri Pembentuk Histamin dari Pindang Badeng Tongkol," J. Pengolah. Has. Perikan. Indones., 2014.

[2] A. R. Shalaby, "Significance of biogenic amines to food safety and human health," Food Res. Int., 1996, doi: 10.1016/S0963-9969(96)00066-X.

[3] Y. Torido, H. Takahashi, T. Kuda, dan B. Kimura, "Analysis of the growth of histamine-producing bacteria and histamine accumulation in fish during storage at low temperatures," Food Control, 2012, doi: 10.1016/j.foodcont.2012.01.009.

[4] D. D. Rawles, G. J. Flick, dan R. E. Martin, "Biogenic Amines in Fish and Shellfish," Adv. Food Nutr. Res., 1996, doi: 10.1016/S1043-4526(08)60076-5.

[5] W. Mangunwardoyo, R. A. Sophia, dan E. S. Heruwati, "Seleksi dan pengujian aktivitas enzim 1-histidine decarboxylase dari bakteri pembentuk histamin," Makara Sci. Ser., 2010, doi: 10.7454/mss.v11i2.292.

[6] G. H. F. Vieira, J. A. Mourão, Â. M. Ângelo, R. A. Costa, dan R. H. S. dos F. Vieira, "Antibacterial effect (in vitro) of Moringa oleifera and Annona muricata against gram positive and gram negative bacteria," Rev. Inst. Med. Trop. Sao Paulo, 2010, doi: 10.1590/S003646652010000300003.

[7] M. G. Rajanandh, M. N. Satishkumar, K. Elango, dan B. Suresh, "Moringa oleifera Lam. a herbal medicine for hyperlipidemia: A pre-clinical report," Asian Pacific J. Trop. Dis., 2012, doi: 10.1016/S2222-1808(12)60266-7.

[8] A. Bukar, A. Uba, dan T. Oyeyi, "Antimicrobial profile of Moringa oleifera lam. extracts against some food - borne microorganisms," Bayero J. Pure Appl. Sci., 2010, doi: 10.4314/bajopas.v3i1.58706.

[9] A. O. Oluduro, "Evaluation of Antimicrobial properties and nutritional potentials of Moringa oleifera," Malays. J. Microbiol., 2012.

[10] B. Mendieta-Araica, E. Spörndly, N. Reyes-Sánchez, F. Salmerón-Miranda, dan M. Halling, "Biomass production and chemical composition of Moringa oleifera under different planting densities and levels of nitrogen fertilization," Agrofor. Syst., 2013, doi: 10.1007/s10457012-9525-5.

[11] S. Aminah, T. Ramdhan, dan M. Yanis, "Syarifah Am inah et. al. : Kandungan Nut risi dan Sifat Fungsional Tanaman Kelor ( Moringa oleifera )," Bul. Pertan. Perkota., 2015.

[12] S. R. Rachmawati dan J. Suriawati, "Identifikasi senyawa 
kimia dan nilai gizi ekstrak air daun kelor (Moringa oleifera l.) sebagai pengawet alami mie basah," Sanitas $J$. Teknol. dan Seni Kesehat., 2019, doi: 10.36525/sanitas.2019.11.

[13] S. T. Pratiwi, Mikrobiologi Farmasi. 2008.

[14] S. M. Widayanti dan H. . Permana, A.W. Kusumaningrum, "Kapasitas dan kadar antioksidan ekstrak tepung kulit buah manggis (Garcinia mangostana l.) pada berbagai pelarut dengan metode maserasi," Jurnal Penelitian Pascapanen Pertanian, vol. 6, no. 2. hal. 61-68, 2009, doi: 10.21082/jpasca.v6n2.2009.61-68.

[15] B. T. dan S. I. Herlina Rante, "Isolasi fungi endofit penghasil senyawa antimikroba dari daun cabai Katokkon (Capsicum Annuum L Var. Chinensis) dan profil KLT bioautografi,” Maj. Farm. Dan Farmakol., 2013.

[16] A. M. Abdalla, H. Y. Alwasilah, R. A. H. Mahjoub, H. I. Mohammed, dan M. Yagoub, "Evaluation of Antimicrobial activity of Moringa oleifera Leaf extracts against Pathogenic bacteria Isolated from Urinary tract infected Patients," J. Adv. Lab. Res. Biol., 2016.

[17] I. Pratiwi, "Uji antibakteri ekstrak kasar daun acalypha indica terhadap bakteri Salmonella choleraesuis dan Salmonella typhimurium," Surakarta, 2009. In Indonesian.

[18] R. S. Harsanti dan R. M. Yasi, "Pengaruh jenis pelarut pada ekstrak daun kelor (Moringa oleifera) terhadap mortalitas larva Aedes aegypti," Edubiotik J. Pendidikan, Biol. dan Terap., 2019, doi: 10.33503/ebio.v4i02.506. In Indonesian.

[19] R. Sulistyawati dan P. Y. Pratiwi, "Pengaruh pemberian ekstrak etanol daun kelor (Moringa oleifera l.) terhadap aktivitas analgesik dan antiinflamasi melalui ekspresi enzim siklooksigenase," Pharmaciana, vol. 6, no. 1, hal. 31-38, 2016, doi: 10.12928/pharmaciana.v6i1.3043. In Indonesian.

[20] M. Veronika, E. Purwijantiningsih, dan S. Pranata, "Efektivitas ekstrak daun kelor (Moringa oleifera) sebagai bio-sanitizer tangan dan daun selada (Lactuca sativa)," vol. 4, hal. 1-15, 2017. In Indonesian.

[21] R. O. B. Wijesekera, The medicinal plant industry. 2017.

[22] Technical Committee ISO/TC 34, "International Standard ISO 4833-1 Microbiology of the food chain - Horizontal method for the enumeration of microorganisms," vol. 2013, hal. 1-9, 2013.

[23] Y. Kumar, D. N. Yadav, T. Ahmad, dan K. Narsaiah, "Recent Trends in the Use of Natural Antioxidants for Meat and Meat Products," Compr. Rev. Food Sci. Food Saf., 2015, doi: 10.1111/1541-4337.12156.

[24] A. Sumbono, Biokimia Pangan Dasar. Jakarta: Deepublish, 2016. In Indonesian.

[25] Handoyo, Kimia Anorganik. Jakarta: Erlangga, 1995. In Indonesian. 